\title{
Engineering Change Implications on Product Design: A Review of the Literature
}

\author{
Inayat Ullah ${ }^{1, a}$, Dunbing Tang ${ }^{1, b}$ and Leilei Yin ${ }^{1, c}$ \\ ${ }^{1}$ College of Mechanical and Electrical Engineering, Nanjing University of Aeronautics and \\ Astronautics, Nanjing 210016, China. \\ aanykhattak@yahoo.com, bd.tang@nuaa.edu.cn, cyllwyp@163.com
}

Keywords: Engineering change, Product life cycle, Change propagation, Literature review.

\begin{abstract}
Engineering changes are inexorable and can arise at any phase of the product life cycle. To capture the maximum market shares manufacturers have to effectively and efficiently manage engineering changes. This paper provides overview of ECM and perspective on the published academic literature related to product engineering changes. The aim is to give an idea and understanding about the engineering changes in product to the new researchers. Engineering changes can be taken in both aspects such as an opportunity to enhance the product performance and as a burden, resulting in a rework, which utilizes resources, time and cost. It is paramount that the impact of engineering changes be identified, assessed and implemented as early as possible. Different methods/tools have been devised to better understand the engineering change phenomenon and to control the changes. ECM can help to mitigate the potential of negative consequences arising from uncertainties during the product life cycle. In this paper the significant aspects of the engineering changes have been discussed and highlighted the methods/tools that are proposed by the researchers. The review shows the prominence of ECM in a product life cycle.
\end{abstract}

\section{Introduction}

Increasing competitiveness in the market due to fast growing change environment forces the manufacturers to pursuit ways to produce a high quality product at the lowest cost with the minimal lead time. To reduce the risk and the manufacturing time, companies promoted to focus on the incremental products. Customers desire reliable \& efficient products, therefore they esteem tried \& tested artefact with improved parts. In case of incremental products, retaining the existing design significantly reduces the cost and also the manufacturing lead time. Most of the new designs are not developed from the scratch, but designed through modifications and changes to the existing design [1]. These products have new functions, characteristics and performances that rely on the existing product design. In the initial product designing stage, the designers come across the intimidating task of assessing the engineering parameters which effectively improve the product performance. These parameters should be focal point throughout the product development. Traditionally the designers select theses parameter based on the knowledge gained by experience. For identifying the key engineering parameters during the conceptual design a domain-independent methodology has been proposed in [2] by Kaldate. The information regarding product parameters increases in quantity and also in quality as the design proceeds and provides a better insight of the design issues.

The advice "do it right the first time" is illusory and far away from real life [3]. Engineering changes have great influences on product developing and production activities, hence making product development very costly and time consuming [4]. In the early decades the engineering changes were predominantly seen as a problem. People were reluctant to implement the change management system. From the past few decades it has been seen that industrialist take it as an opportunity and source of innovation \& creativity [5, 6]. Engineering changes can be taken into account as a driving force for incremental product improvement. Keeping in view the above, knowledge attained from engineering changes is very helpful and useful for the design and development of the product. In manufacturing, today’s markets and customers wish change so 
quickly [7]. Engineering changes arises frequently for continual improvement of the system/product and determines approximately 70 to $80 \%$ of the final product cost [8].

The paper is structured in such a way that in Section 2, definitions of the key terminologies used in the field of ECM are presented. Section 3 states the methodology to carry out the literature review. Section 4 describes definition and categorization of ECs, objective of ECM and handling approaches. In section 5, product architecture has been elaborated. Section 6 gives an idea about the change propagation. Section 7 discusses the engineering change process. In section 8, tools and methods to support ECM have been presented. Section 9 gives the summary of the paper.

\section{Definitions}

There are some key terminologies which are used in the field of ECM and are defined as follows:

- Function is the intention or purpose of the artefact $[9,10]$ and Hubka called it, duty of the artefact [11].

- Behaviour describes what the artefact does and how it achieves it functions or purpose [12].

- Structure describes distinctive variables that identify the artefact and their interactions [13] and structure can also be defined as a set of entities connected in a meaningful way [14].

- Impact is the "average proportion of the design work that will need to be redone if the change propagates" [15].

- Likelihood is defined as the "average probability that a change in the design of one sub-system will lead to a design change in another by propagation across their common interface” [15]

\section{Methodology}

The research commenced with a rigorous literature review on current ECM practices. To conduct the literature review, specific to the product, different journals and conferences were focused for review of the topic.

\section{Literature selection}

Inorder to carry out the review on the selected topic the word "Engineering change" was searched in the articles title and abstracts. The search engine "Google Scholar" and the journals to which the access is provided by the university were the main source for downloading the related papers. Total 278 papers were downloaded for the literature review from different sources.

\section{Journals and conferences}

The collection of publications has been done by consulting multitude of journals and conferences related to the product design and ECM as a source for literature review. The main journals which were used as a source for downloading the related papers/articles are: Journal of Engineering Design, Computers in Industry, Research in Engineering Design, IEEE Transaction on Engineering Management, Computer Aided Design and Applications, Design Studies, International Journal of Computer Integrated Manufacturing, Computer and Industrial Engineering, Journal of Computing and Information Science in Engineering etc. Conferences proceedings which were included in the literature review are: International Design Conference (IDC), ASME International Design Engineering Technical Conference, CIRP International Conference on Life Cycle Engineering, Conference on System Engineering Research, International Conference on Engineering Design (ICED) and International Design Structure Matrix Conference (IDSMC).

\section{Distribution of Publications over year}

278 papers were downloaded for review which contains $55 \%$ of the papers from the journals and $45 \%$ of the papers were from conferences. Only 04 papers were found from the resources discussed above before 1990 and they are not included in the graph. The publications distribution in figure 1 shows increase until 2007. 31 publications out of 278 were published in 2007 with a peak of $12.16 \%$. There is a decrease in the publication after 2007 upto 2013. In 2014 there is again a slight rise in the graph with 15 publications. From this graph it has been concluded that interest in the field of ECM steadily increased till 2007 where it get its peak. Form 2007 onwards upto 2013 there 
is a decrease but still remains at the higher level than the period before 2004. In 2014 there is a slight increase in the publications.

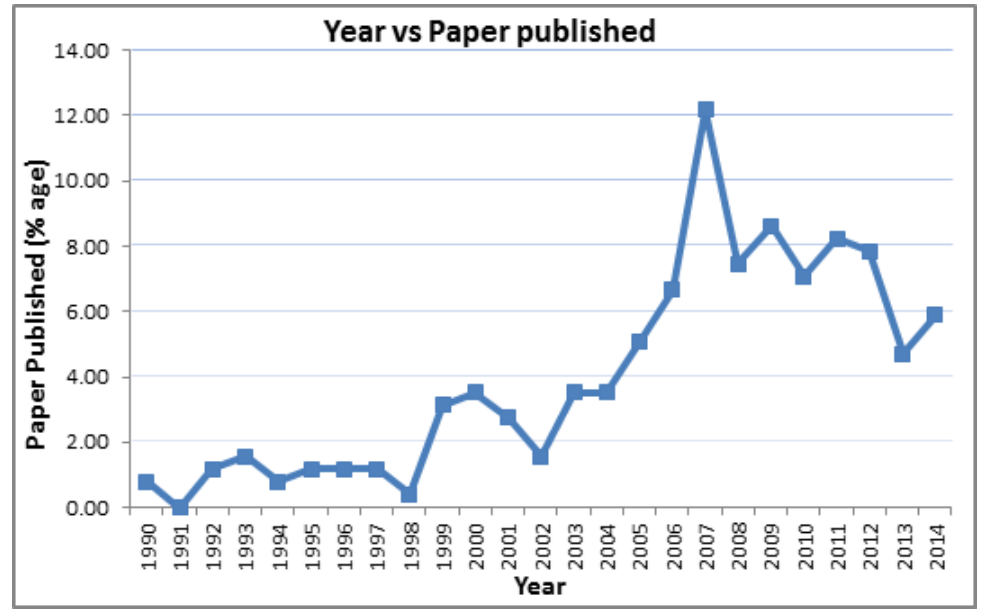

Fig. 1 Paper publications over year

\section{Engineering Change}

Engineering changes are considered as a normal part of the product life cycle. Engineering changes are defined in a different perspective by the numerous researchers. Wright defines the engineering changes as the modification to the component of a product which normally takes place when the product enters the production stage [16]. Engineering change (EC) can also be defined as "changes and/or modifications to released structure (fits, forms and dimensions, surfaces, materials etc.), behaviour (stability, strength, corrosion etc.), function (speed, performance, efficiency, etc.), or the relations between functions and behaviour (design principles), or behaviour and structure (physical laws) of a technical artefact"' [17]. Engineering changes can inject turbulence into a previously stable operation, changing entities rapidly and severely [18]. Engineering changes are further classified into three categories, named as immediate, mandatory and convenient change which represents different degree of urgency for engineering change implementation [19]. ECM consumes 30 to $50 \%$, sometime upto $70 \%$ of the production capacity [20] and represents 20 to $50 \%$ of manufacturing tool cost [21]. Some other reports suggest that engineering changes usually consumes around one third of the engineering design capacity [22, 23].

\section{Engineering Change Management}

According to Jarratt et al. "ECM refers to the organisation and control of the process of making alterations to products" [24]. Coates et al. in [25] discuss about engineering management and also emphasise the need to coordinate communication, scheduling and resources. Effectively managing the engineering changes can ensure that the latest versions of modifications, product and process data are at the right place at the right time. ECM depends upon the engineering processes, management and engineering \& information technologies [26]. The objective of ECM is to minimize the occurrence of changes, and if the changes occur then deal these changes in a proper way to reduce the loss in terms of cost, time, quality and customer satisfaction. For the better management of the changes Wildemann and Gemmerich suggested three strategies $[27,28]$ and Fricke gives five attributes / guidelines [22].

First, reduce the number of changes to avoid the occurrence of changes as far as possible. Changes should be detected as early as possible to reduce the impact of changes. Evaluate the impact of changes and prioritize the changes as per the impact value effectively. Then changes should be implemented in the less time, incurring lower cost and with better quality. At last the firm should learn from these changes and continuously improve the management system of engineering changes.

\section{Engineering Change Cost at different design stages}

Each engineering change involves the cost. If a change is issued early during the development process, then it will have minimal investments. These investments increase extremely as the design moves toward maturity for full-scale production, the cost of an engineering change in each 
successive phase within the product life cycle being ten times more than the previous phase [29] as depicted by figure 2. Edge and Smith have formulated a "factor of ten" rule for the costs of defects and failures in electronic components [30]. Design change increases the cost and time of the design to a substantial portion of amount and duration [31]. In manufacturing, processing changes often absorb from $20 \%$ to over $50 \%$ of the product development capacity [32].

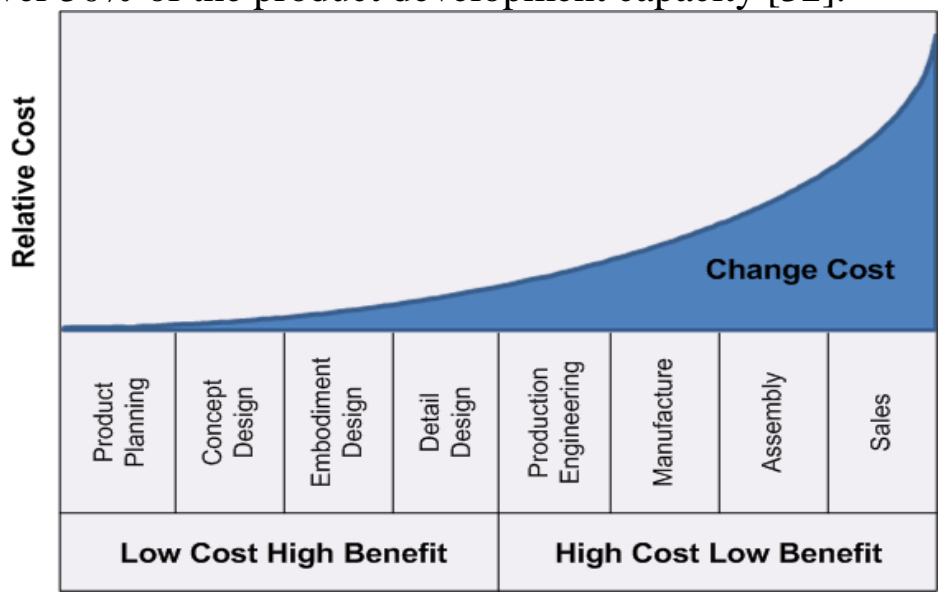

Fig. 2 Change cost at different design phases [33]

If multiple changes are required to a single product then all the changes should be incorporated at the same time to minimise the cost of change and the disruption in production [34]. In order to efficiently and effectively deal with the introduction of a new product solution, it is paramount that the impact of engineering change (i.e., effort, span time, technical difficulty, quality, fulfilment of customer requirements, and cost) be identified and assessed as early as possible within the product life cycle [35]. On the other hand, evidence from empirical investigations [36] and from the literature [37] show that $70-80 \%$ of total product cost is decided during early design stages where $56 \%$ of changes occur after the initial phase, of which $39 \%$ are avoidable.

\section{The categorization of engineering changes}

A numerous studies have been conducted to evaluate the nature and importance of engineering changes. Lindermann and Reichwald categorize changes by distinguishing them into a problem or innovation oriented [20]. Eckert et al extended that categorization by considering the origin of the change [5]. Changes are caused by new customer requirement, new legislation, supplier constraints, error correction, performance improvement, technological changes etc. [37, 38]. To make changes, a change process is usually initiated by a reason of change [39]. Engineering changes can be mainly classified into two categories, as emergent changes and initiated changes.

Emergent changes arise from the product itself due to the error during the design process. These changes are also termed as an unintended and occur when some aspect of the system design requires changing because of errors [40]. The reasons of emergent changes are error rectification and safety etc. Initiated changes are originating from the external source. Initiated changes are those intended by the stakeholder. In this perspective, innovation is considered as a part of initiated changes for product enhancement [5]. The reasons of initiated changes are customer, legislation, production, cost reduction, performance, maintainability, technological progress and durability etc. To manage engineering changes, different approaches have been suggested in the literature. These approaches can be divided in to three groups [41]. The first group pursue the improvement of engineering changes handling through systematic engineering change processes [19, 24]. Second group attempt to create more changeable products by managing the future changes $[42,43]$ and last group predict undesired changes outcome by modelling techniques and its probable propagation [44, 45].

\section{Product Architecture}

Product is basically made up of several components. It is fact that the product architecture has a strong influence on the success of product [46]. The product architecture is here defined as the arrangement of the functional elements of a product into several physical building blocks, including 
the mapping of the functional element to physical components [47]. Architecture can influence the product change, product variety, component standardization and product performance [48, 49]. Product architecture is the arrangement of the parts by which the function of the product is allocated to the physical components. It can be further defines as (1) the arrangement of the functional elements; (2) the mapping from functional elements to physical components (3) the specification of interfaces among the interacting physical components [48]. The main aspect of the product architecture is the degree to which it is modular or integral [50, 51]. Product architecture elaborates that by changing a particular component, which functional elements will be influenced. Products can be composed of sub-systems that are modular in the way that they link together, but everyone is highly integrated [52]. In real design situation, the designer has to make trade-off between the modular and integral architecture [53].

\section{Product Classification}

Products can be classified into main three categories based on their structure/architecture. Complex (Integral) product architecture consists of a complex (not one-to-one) mapping from functional elements to physical components and/or coupled interfaces between the components [48]. The complexity of technical systems depends on the heterogeneity and quantity of different elements and their connectivity pattern [54]. In the integral architecture each physical components carries out more than one functional element and it is known as a function sharing [55].

Modular product architecture can be defines as the clustering of the components such that the degree of interaction/dependency is maximized within the group (module) and minimized between the groups (outside module) [56]. A change to one module can be made without changing the other modules if the interfaces remain unchanged. In modular product modules can be defined as the physical structure which has one-to-one relation with the functional structure. They can be thought of quite simply as a building block with defined interfaces [57]. Modular products may be defined as machines, assemblies or components that accomplish an overall function through combination of distinct building blocks or modules [58]. Modular product design has been proved to be efficient to reduce the design efforts [59].

Product family can be defined as the multitude products with distinctive characteristics and function using common parts/components. The advantage of developing a product family is that it enables a company to offer a great variety of products that are highly differentiated, yet sharing substantial fraction of their components [60]. Product family design is extensively practiced in the industry as a cost-effective approach to satisfy the increasing market trend towards smaller batch and more variety orders [61, 62]. In the product family, each product is different from one another and the common parts are used in number of product models. When a particular subassembly is used on a variety of products, saving can be possible - a process termed "Modularizing Product Families" [63]. Product platforms are means to control variety [64]. Part family is a set of parts that serve a related set of market applications - they are functionally similar, and share a common technology base, and lead to better processes for life-cycle design [65].

\section{The classification of product components / sub-systems}

The components/parts or sub-systems of the product are interlinked to eachother. Eckert [5], identify four types of change propagation component behaviours named as multiplier, absorber, carrier \& constant and these represent four different situations. When the change is initiated by one component and it propagates to the other components via linkages between them, so different components behaves in a different ways. These classifications are illustrated in the figure 3.

Multipliers are those components which enhance the change problem and thus making the situation worst. Such components may cause an "avalanche" of changes [66, 22] or referred as the snowball effect [67]. Such changes have the major effect on the budget, product lead time and the company. Absorber eradicates or absorbs all the changes. If the number of input change is more than the number of output changes then it would be partial absorber. But if the numbers of output changes are zero then it would be complete absorber and thus accommodating all the changes. The later situation is uncommon. Absorbers alleviate the complexity of the change propagation. Carrier can be defined as the components which neither add nor reduce the number of changes. It means 
that the input to that component is equal to the output. They replace the changes with the new one from the intermediate component [68]. Constant are the components which remain unchanged and the change is being passed without any effect [5,68]. They just transfer the change from one component to the other components by which they are interlinked.
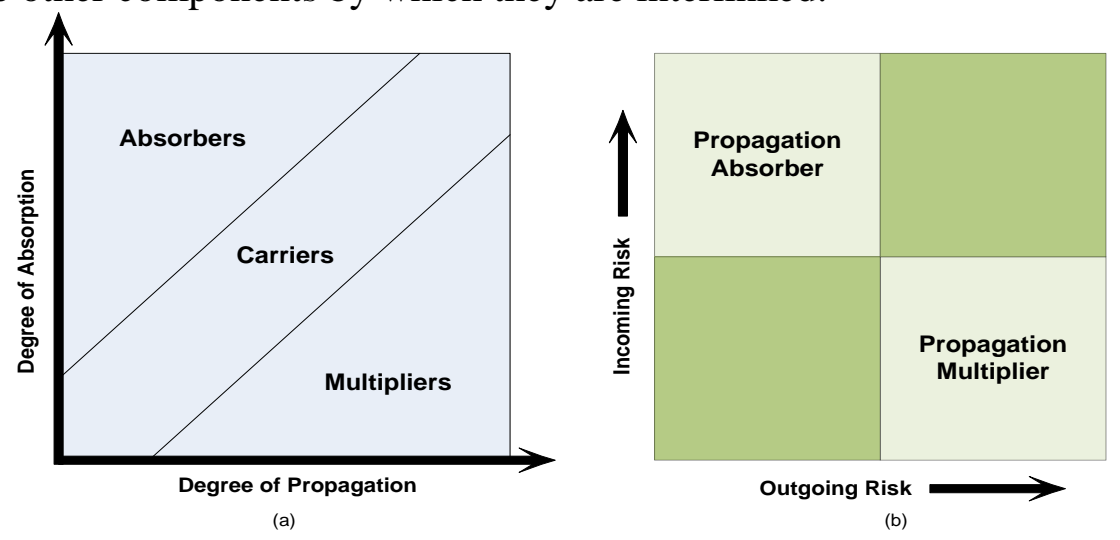

Fig. 3 (a) Representation of the change propagation characteristics of components [5] and (b) Component classification based on change risk [69]

\section{Change propagation}

Change propagation is a phenomenon by which one change triggers a series of others changes [70], can potentially distract the manufacturing process [71]. Change propagation can be considered as the cause-effect, cause-effect pattern [72]. Change propagation is an issue that affects both the product and the organization [73].The initiated change is the primary cause of the propagation and the effect of that change becomes the cause of the subsequent stage. Engineering change propagation can be better understood by the change propagation model in figure 4 . The EC1 is the primary cause for the EC2 and triggers a series of other changes.

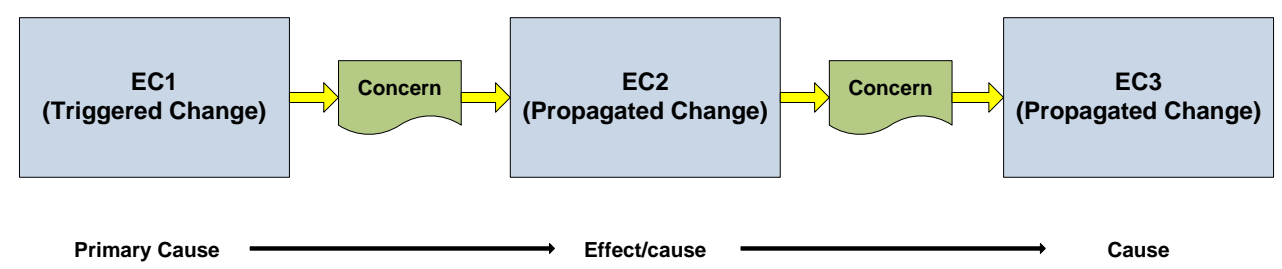

Fig. 4 Change propagation model [3]

In the products, components are interconnected through the parameters such as geometry, spatial, material, function and behaviour. Therefore changing in any one of these parameters may initiate changes in the several other parameters of the system [74, 5]. Second-order change propagations are most likely to propagate and are difficult to foresee at the time of change [75]. It is not necessary that the changes can propagate only to those components which are directly linked to eachother but also to other components which has indirect connection.

\section{Engineering Change Process}

In order to control the consequences of engineering changes many companies have adopted the formal engineering change procedure as shown in the Figure 5. The process gets it ignition from the so called change trigger. A well-founded change request can be raised by the firm's employee or by the external source to carry out the engineering change. Then the potential solutions to the engineering change request should be identified and impact \& risk assessment should be carried out to prioritize the possible solutions. It is the most critical phase in the engineering change process to evaluate the possible impact of changes. Impact upon the product itself and the effect on the development process must be considered during this phase. Selection and approval before the 
implementation of such changes must be done by the change board/committee. Finally the approved solution should be implemented and after a certain period of time, it should be reviewed to check whether the change was successful or not. The generic engineering change process can be divided into three main stages as shown in the Figure 5. Communication is the key factor required between different domains within the company in engineering change process depending upon how far the product is in the life cycle. Engineering change propagation procedure can maintain consistency by propagating ECs in a base product definition to product data views [76].

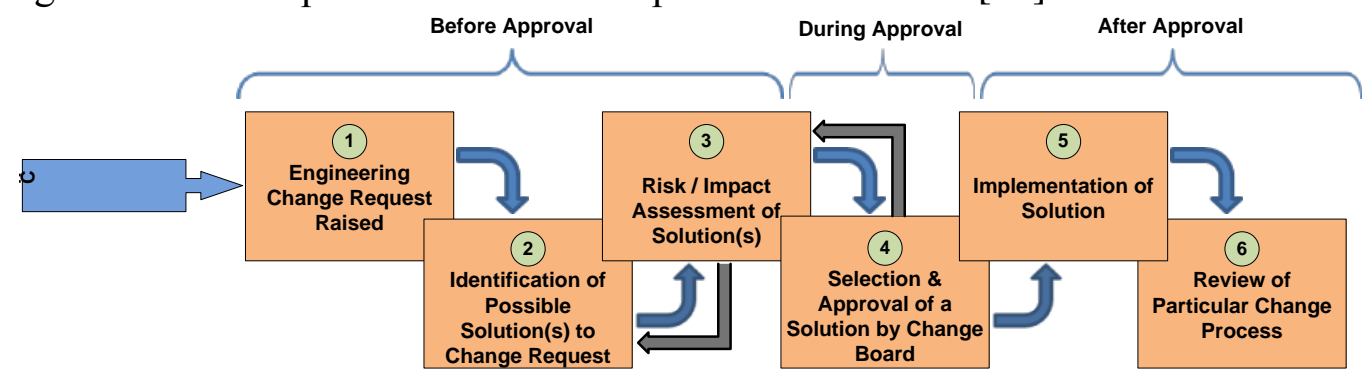

Fig. 5 Generic engineering change process (adapted from [27])

\section{Tools and methods to support engineering change management}

A variety of tools and methods have been proposed by the numerous researchers to support the firms to manage the engineering changes in the products effectively and efficiently. Most of them are based on dependency structure matrix (DSM) [77]. 14 out of 278 publications have proposed tools for better management of engineering changes. Detail list of the methods/tools proposed by the researchers have been presented in table 1.

Table 1 Engineering change management tools/methods

\begin{tabular}{|c|c|c|c|c|}
\hline $\begin{array}{c}\text { Sr. } \\
\#\end{array}$ & $\begin{array}{l}\text { Tool / Method } \\
\text { Description }\end{array}$ & Purpose & Author & $\begin{array}{c}\text { Publication } \\
\text { year }\end{array}$ \\
\hline 1 & Raffaeli et al. & $\begin{array}{l}\text { Representing modular products on multilevel basis } \\
\text { and considering the change propagations in product } \\
\text { families [78] }\end{array}$ & $\begin{array}{l}\text { Roberto, } \\
\text { Malatesta, } \\
\text { Marilungo }\end{array}$ & 2013 \\
\hline 2 & $\begin{array}{l}\text { CPM Software } \\
\text { tool }\end{array}$ & $\begin{array}{l}\text { This tool is the implementation of the CPM } \\
\text { methodology [37]. }\end{array}$ & $\begin{array}{l}\text { Keller, Eckert, } \\
\text { Clarkson }\end{array}$ & 2008 \\
\hline 3 & Ahmed et al. & $\begin{array}{l}\text { It is cross-domain approach to decompose a design } \\
\text { and identify possible change propagation linkages [79] }\end{array}$ & $\begin{array}{l}\text { Ahmad, Wynn, } \\
\text { Clarkson }\end{array}$ & 2012 \\
\hline 4 & $\begin{array}{l}\text { Mathematical } \\
\text { model and } \\
\text { computer tool }\end{array}$ & $\begin{array}{l}\text { This models predict the risk of change propagation } \\
\text { in terms of likelihood and impact of change [15]. }\end{array}$ & $\begin{array}{l}\text { Clarkson, } \\
\text { Simons, Eckert }\end{array}$ & 2001 \\
\hline 5 & Modelling tool & $\begin{array}{l}\text { In this modelling tool, specifically a higher order } \\
\text { DSM is used to predict EC propagation [75]. }\end{array}$ & $\begin{array}{l}\text { Morkos, Shankar, } \\
\text { Summers }\end{array}$ & 2012 \\
\hline 6 & $\begin{array}{l}\text { VV\&T } \\
\text { Implementation } \\
\text { tool }\end{array}$ & $\begin{array}{l}\text { Validation, verification and testing (VV\&T) tool } \\
\text { assist in mitigating the negative effects of engineering } \\
\text { change propagation and help to minimize the } \\
\text { opportunities for human error [80]. }\end{array}$ & $\begin{array}{l}\text { Phelan, Summers, } \\
\text { Guarneri }\end{array}$ & 2014 \\
\hline 7 & Software tool & $\begin{array}{l}\text { The software tool is used to represent the product } \\
\text { architecture, collect the product information and } \\
\text { individuate the change propagation paths in order to } \\
\text { automate the change impact analysis [81]. }\end{array}$ & $\begin{array}{l}\text { Raffaeli, } \\
\text { Germani, } \\
\text { Graziosi, } \\
\text { Mandorli }\end{array}$ & 2007 \\
\hline 8 & $\begin{array}{l}\text { ACE } \\
\text { methodology }\end{array}$ & $\begin{array}{l}\text { Allied Concurrent Engineering based ECM } \\
\text { methodology [26]. }\end{array}$ & $\begin{array}{l}\text { Chen, Shir, } \\
\text { Shen }\end{array}$ & 2010 \\
\hline 9 & $\begin{array}{l}\text { Attribute based, } \\
\text { object oriented } \\
\text { approach }\end{array}$ & $\begin{array}{l}\text { This approach models the integrated content of a } \\
\text { product by characterizing its parts and associated } \\
\text { requirements with attributes and linkages [82]. }\end{array}$ & $\begin{array}{l}\text { Chen, Liao, } \\
\text { Lin }\end{array}$ & 2014 \\
\hline 10 & $\begin{array}{l}\text { DSS } \\
\text { methodology }\end{array}$ & $\begin{array}{l}\text { It helps managers to understand the cost and risk of } \\
\text { change. [83] }\end{array}$ & $\begin{array}{l}\text { Zhao, } \\
\text { Oduncuoglu }\end{array}$ & 2014 \\
\hline
\end{tabular}




\begin{tabular}{|c|c|c|c|c|}
\hline 11 & $\begin{array}{l}\text { Model based } \\
\text { method }\end{array}$ & $\begin{array}{l}\text { By fuzzy theory, changes cost of each part in terms of } \\
\text { financial, time and structural criteria is estimated [84]. }\end{array}$ & $\begin{array}{l}\text { Seyed Amir } \\
\text { Ahmad Afshar }\end{array}$ & 2014 \\
\hline 12 & $\begin{array}{l}\text { FBS Linkage } \\
\text { method }\end{array}$ & $\begin{array}{l}\text { Multi-domain change propagation model based on } \\
\text { the concept of functional reasoning and the CPM [85] }\end{array}$ & $\begin{array}{l}\text { Bahram, Clarkson } \\
\text { Nicholas, Tom, }\end{array}$ & 2014 \\
\hline 13 & Improved CPM & $\begin{array}{l}\text { Requirement based benchmarking approach to } \\
\text { improve existing CPM }\end{array}$ & $\begin{array}{l}\text { Bahram, Clarkson } \\
\text { Nicholas, David, }\end{array}$ & 2013 \\
\hline 14 & $\begin{array}{l}\text { Matrix based } \\
\text { modelling }\end{array}$ & $\begin{array}{l}\text { Enhance the traceability of design changes occurring } \\
\text { between functional and structural domains [86]. }\end{array}$ & $\begin{array}{l}\text { Genyuan, James, } \\
\text { Owodunni, }\end{array}$ & 2013 \\
\hline
\end{tabular}

\section{Summary}

The utmost objective of engineering change is to enhance the performance of redesign product parts or to be produced effectively. Engineering changes (EC) in the product can be raised throughout the product lifecycle, resulting in a severe profit/loss if not managed effectively. Change propagation causes large delays and unexpected spending. Engineering changes are necessary to improve the product's quality and are the source for innovation. In recent years various methods on change propagation have been proposed by the researchers. For instance, some methods indicates potential change propagation paths, some calculating the risk for a change to propagate, some methods map physical components whereas other map functional, behavioural and parameter linkages in the product. Some methods are limited to the specific phase of the product lifecycle and some are applied to all the product development stages.

It has been revealed from the literature review that to manage engineering changes effectively, it is paramount to understand the impact, likelihood and propagation path of engineering changes. Knowledge from previous design change cases is an important asset for companies. Many design conflicts arising from change analysis can be tackled by reusing well-formalised and managed knowledge abstracted from previous design cases. Product family design is widely used in the industry due to its cost effectiveness, improved productivity and quality. Several engineering change management approaches have been proposed by the researchers but they are limited to the analysis of the single product and very little consideration has been given to product family.

It is evident from literature that the amount of research carried out in the field of ECM has significantly increased during the last two decades. More academic efforts are required to develop tools and manage knowledge to facilitate firms to enhance their engineering change processes.

\section{Acknowledgments}

The authors are grateful for the financial support given by National Natural Science Foundation of China (NSFC) under Grant No. 51175262 and Jiangsu Province Science Foundation for Excellent Youths under Grant BK2012032.

\section{References}

[1] Otto K, Wood K. Product Design: Techniques in Reverse Engineering, Systematic Design, and New Product Development. New York, USA: Prentice-Hall, 2001.

[2] A. Kaldate, D. Thurston, H. Emamipour, et al. Engineering Parameter Selection for Design Optimization during Preliminary Design. Journal of Engineering Design, Vol. 17 (2006) No. 4, p. 291-310.

[3] Ernst Fricke, Bernd Gebhard, Herbert Negele, et al. Coping with Changes: Causes, Findings, and Strategies, Division of Astronautics, Technische Universität München, Germany, 6 August 2000.

[4] Huang G.Q, Yee W.Y, Mak K.L. Current Practice of Engineering Change Management in Hong Kong Manufacturing Industries. Journal of Materials Processing Technology. Vol. 139 (2003) No. (1-3), p. 481-487. 
[5] Eckert C, Clarkson P.J, Zanker W. Change and Customisation in Complex Engineering Domains. Res Eng Des. Vol. 15 (2004) No. 1, p. 1-21.

[6] Balogun J, Jenkins M. Re-Conceiving Change Management: A Knowledge-Based Perspective. European Management Journal. Vol. 21 (2003) No. 2, p. 247-257.

[7] Kohler C, et al. A Matrix Representation of the CPM/PDD Approach as a Means for Change Impact Analysis. International Design Conference. Dubrovnik, Croatia. 19-22 May 2008, p. 167174 ,

[8] McIntosh K. G. Engineering Data Management: A Guide to Successful Implementation, (New York: McGraw-Hill), 1995.

[9] Hybs I, Gero J.S. An Evolutionary Process Model of Design. Design Studies. Vol. 13 (1992) No. 3, p. 273-290.

[10] Qian L, Gero J.S. Function-Behaviour-Structure Paths and their Role in Analogy Based Design. Artificial Intelligence for Engineering Design, Analysis and Manufacturing. Vol. 10 (1996) No. 4, p. 289-312.

[11] Hubka V. Principles of Engineering Design. 1st ed. Zurich: Butterworth \& Co Ltd. 1982, p.118.

[12] Gorti S.R, et al. An Object-Oriented Representation for Product and Design Processes. Computer Aided Design. Vol. 30 (1998) No.7, p. 489-501.

[13] Kuipers B. Commonsense Reasoning about Causality: Deriving Behaviour from Structure. Artificial Intelligence. Vol. 24 (1984) No.1-3, p.169-203.

[14] W.J. Zhang, Y. Lin, Niraj Sinha. On the Function-Behaviour-Structure Model for Design, June 2005.

[15] Clarkson P.J, Simons C, Eckert C.M. Predicting Change Propagation in Complex Design. Proceedings of ASME- Design Engineering Technical Conferences- DETC'01. Pittsburgh, USA, 912 September 2001.

[16] Wright I.C. A Review of Research into Engineering Change Management: Implication for Product Design. Design Studies. Vol. 18 (1999), p. 33-42.

[17] Hamraz B, Caldwell NHM, Clarkson PJ. A Holistic Categorisation Framework for Literature on Engineering Change Management. System Eng. Vol. 16 (2013) No. 4, p. 473-505.

[18] William F. Rowell, Alex H. B. Duffy, Iain M. Boyle, et al. The Nature of Engineering Change in a Complex Product Development Cycle. $7^{\text {th }}$ Annual Conference on Systems Engineering Research. Loughborough University, 20-23 April 2009.

[19] Diprima M. Engineering Change Control and Implementation Considerations. Production and Inventory Management, Vol. 23 (1982), p. 81-87.

[20] Lindermann, Reichwald. Integriertes Anderungsmanamement. Springer, Berlin, Heidelberg New York, 1998.

[21] Huang G.Q. Yee W.Y, Mak K.L. Current Practices of Engineering Change Management in Hong Kong Manufacturing Industries. Journal of Materials Processing Technology. Vol. 139 (2003), p. 481-487.

[22] Fricke E, Gebhard B, Negele H, et al. Coping with Changes: Causes Findings and Strategies. Systems Engineering. Vol. 3 (2000) No. 4, p. 169-179.

[23] Ahmed S, Kanike Y. Engineering Change during a Product's Lifecycle. Paper Presented at the International Conference on Engineering Design (ICED’07). Paris, France, 2007. 
[24] Jarratt T, Clarkson P.J, Eckert C. M. Engineering change. In Design Process Improvement: A review of current practice (Clarkson, P. J. and Eckert, C. M., Eds.), Springer London, UK (2005), p. 262-285.

[25] Coate G, Duffy A, Whitfield I, et al. Engineering management: operational design coordination. J. Eng. Design. Vol. 15 (2004), p. 433-477.

[26] Yuh-Min Chen, Wei-Shin Shir, Chung-Yen Shen. Distributed engineering change management for allied concurrent engineering. International Journal of Computer Integrated Manufacturing, Vol. 15 (2010) No. 2, p 127-151.

[27] H. Wildemann. Änderungsmanagement-Leitfaden zur Einführung eines effizienten Managements technischer Änderungen. TCW, München, 1994.

[28] M. Gemmerich, Zeitorientiertes Management technischer Änderungen, Technol Manage Vol. 3 (1996) No.45.

[29] Jarratt T, Eckert C, Clarkson J.P. Pitfalls of Engineering Change: Change Practice during Complex Product Design. In: Advances in design, 1st edn. Springer series in Advanced Manufacturing, Germany, 2006, p. 413-424.

[30] Edge, J., Smith, D., in Lock, D. (Ed.). Gower Handbook of Quality Management, Gower, Aldershot, 1990.

[31] A.S.T. Chang, J.S. Shih, Y.S. Choo. Reasons and Costs for Design Change during Production. Journal of Engineering Design. Vol. 22 (2011) No. 4, p. 275-289.

[32] Ehrlenspiel K, Kiewert A, Lindemann U, Cost-efficient Design. Berlin, Germany: SpringerVerlag, 2007.

[33] Baxter M., Product Design, Nelson Thornes Ltd, Cheltenham, 1995.

[34] M.W. Kidd, G. Thompson. Engineering design change management. Integrated Manufacturing Systems, 2000, p. 74-77.

[35] Arman Oduncuoglu, Thomson Vince. Evaluating the Risk of Change Propagation. International Conference on Engineering Design, ICED11, Denmark, 15-18 August 2011.

[36] Crossland R, Williams J, McMahon C. An Object-Oriented Modelling Framework for Representing Uncertainty in Early Variant Design. Research in Engineering Design. Vol. 14 (2003) No.3, p. 173-183.

[37] Keller R, Eckert, C.M, Clarkson P.J. Using an Engineering Change Methodology to Support Conceptual Design. Journal of Engineering Design. Vol. 20 (2009) No. 6, p. 571-587.

[38] Eckert C.M, Pulm U, Jarratt T.A.W. Mass Customisation, Change and Inspiration Changing Designs to meet new needs. Proceedings of the 14th International Conference on Engineering Design ICED03, Royal Institute of Technology, Stockholm, Sweden, 2003.

[39] Mohringer S. From Design Errors to Chances - A Computer-Based Error Tracking System in Practice. Strojarstvo, Vol. 49 (2007) No.1, p. 37-43.

[40] Monica Giffin, Olivier de Weck, Gergana Bounova, et al. Change Propagation Analysis in Complex Technical Systems. Journal of Mechanical Design. Vol. 131 (2009).

[41] Edwin C. Y. Koh, Nicholas H. M. Caldwell, P. John Clarkson. A Method to Assess the Effects of Engineering Change Propagation. Res Eng Design. Vol. 23 (2012), p. 329-351.

[42] Martin MV, Ishii K. Design for Variety: Developing Standardized and Modularized Product Platform Architectures. Res Eng Des. Vol. 13 (2002), p. 213-235.

[43] Fricke E, Schulz A. P. Design for Changeability (DFC): Principles to Enable Changes in Systems throughout their Entire Lifecycle. Syst Eng. Vol. 8 (2005), p. 342-359. 
[44] Ho C. J, Li J. Progressive Engineering Changes in Multi-Level Product Structures. Omega Int J Manag Sci. Vol. 25 (1997), p. 585-594.

[45] Cohen T, Navathe S. B, Fulton R. E. C-FAR, Change Favourable Representation. Comput Aided Des. Vol. 32 (2000), p. 321-338.

[46] David F. Wyatt, David C. Wynn, P John Clarkson. A Computational Method to Support Product Architecture Design. ASME International Mechanical Engineering Congress and Exposition, Florida, USA, November 2009, p. 13-19.

[47] Ulrich K.T, Eppinger S.D. Product Design and Development. Third Edition, McGraw-Hill, New York, 2004.

[48] Karl Ulrich. The Role of Product Architecture in the Manufacturing Firm. Research Policy. Vol. 24 (1995) No. 3, p. 419-440.

[49] Yassine A. A, Wissmann L. A. The Implications of Product Architecture on the Firm. Systems Engineering. Vol. 10 (2007) No. 2, p. 118-137.

[50] Eric Bonjour, Ghassen Harmel, Jean Pierre Micaëlli, et al. Simulating Change Propagation between Product Architecture and Development Organization. International Journal of Mass Customisation, Inderscience. Vol. 3 (2011) No. 3, p. 288-310.

[51] Browning T.R. Applying the Design Structure Matrix to System Decomposition and Integration Problems: A Review and New Directions. IEEE Trans. Eng. Mgt. Vol. 48 (2001) No. 3, p. 292-306.

[52] T. Jarratt, C. Eckert, P. J. Clarkson, et al. Product Architecture and the Propagation of Engineering Change. International Design Conference, Dubrovnik, 14 - 17 May, 2002.

[53] Sosa M.E, Eppinger S.D, Rowles C.M. Designing Modular and Integrative Systems. Proceedings of DETC '00: ASME 2000 International Design Engineering Technical Conferences, 2000.

[54] Kaushik Sinha, Olivier L. de Weck. Structural Complexity Quantification for Engineered Complex Systems and Implications on System Architecture and Design. International Design Engineering Technical Conferences, Portland, Oregon, USA, 4-7August, 2013.

[55] Ulrich K. T, Seering W. P. Functional Sharing in Mechanical Design. Design Studies. Vol. 11 (1990) No.4, p. 223-234.

[56] Whitfield R.I, Smith J.S, Duffy A.H.B. Identifying Component Modules. In Proceedings of Seventh International Conference on Artificial Intelligence in Design, Cambridge, UK, 2002, p. 571-592.

[57] Ericsson, Anna, Erixon, et al. Controlling Design Variants: Modular Product Platforms. ASME press ISBN 0-87263-514-7, New York, USA. 1999, p. 145.

[58] Stone, Robert B. A Heuristic Method for Identifying Modules for Product Architectures. Design Studies. Vol. 21 (2000), p. 5-31.

[59] Eric Bonjour, Maryvonne Dulmet, Samuel Deniaud, et al. Propagating Product Architecture Decisions onto the Project Organization: A Comparison Between two Methods. International Journal of Design Engineering. Vol. 2 (2009) No. 4, p. 451-471.

[60] Ding-Bang Luh, Yao-Tsung Ko, Chia-Hsiang Ma. A Structural Matrix-Based Modelling for Designing Product Variety. Journal of Engineering Design. Vol. 22 (2011) No. 1, p. 1-29.

[61] S. Davis. From Future Perfect: Mass Customization. Planning Review, Vol. 17 (1989) No. 2, p.16-21. 
[62] J. Ping, B. Victor, A. Boyton. Making Mass Customization Work. Harvard Business Review. Vol. 71 (1993) No. 5, p.108-111.

[63] Otto K. A Process of Modularizing Product Families. Proceedings International Conference on Engineering Design, Design Management, Glasgow, UK, 2001, p. 523-530.

[64] Erens F. The Synthesis of Variety, Dissertation, Eindhoven University of Technology, 1996.

[65] Simpson T. W. Product Platform Design and Customization: Status and Promise. Artificial Intelligence for Engineering Design, Analysis and Manufacturing. Vol. 18 (2004), p. 3-20.

[66] Eckert C.M, Clarkson P.J, Zanker W. Change and Customisation in Complex Engineering Domains. Research in Engineering Design, in press.

[67] Terwiesch C, Loch C.H. Managing the Process of Engineering Change Orders: The Case of the Climate Control System in Automobile Development. Journal of Product Innovation Management. Vol. 16 (1999) No. 2, p. 160-172.

[68] Genyuan Fei, James Gao, Oladele Owodunni, et al. A method for engineering design change analysis using system modelling and knowledge management techniques. International Journal of Computer Integrated Manufacturing. 19 May 2011, p. 535-551.

[69] R. Keller, C.M. Eckert, P.J. Clarkson. Using an Engineering Change Methodology to Support Conceptual Design. Journal of Engineering Design. Vol. 20 (2009) No. 6, p. 571-587.

[70] Clarkson PJ, Simons C, Eckert C. Predicting Change Propagation in Complex Design. J Mech Des. Vol. 126 (2004) No. 5, p. 788-797.

[71] Williams O J. Change Control in the Job Shop Environment. Proceedings of the 26th Annual International Conference of the American Production and Inventory Control Society, Toronto, Canada, 1983, p. 496-498.

[72] Prabhu Shankar, Beshoy Morkos, Joshua D. Summers. Reasons for Change Propagation: A Case Study in an Automotive OEM. Res Eng Design. DOI 10.1007/s00163-012-0132-2, 14 March 2012.

[73] Edwin CY Koh, P John Clarkson. A Modelling Method to Manage Change Propagation. International Conference on Engineering Design, ICED'09, STANFORD, USA, 24-27 August 2009.

[74] Eckert C, Zanker W, Clarkson PJ. Aspects of a Better Understanding of Changes. Paper Presented at the International Conference on Engineering Design, ICED’01, Glasgow, UK, 21-23 August 2001.

[75] Beshoy Morkos, Prabhu Shankar, Joshua D. Summers. Predicting Requirement Change Propagation, Using Higher Order Design Structure Matrices: An Industry Case Study. Journal of Engineering Design. Vol. 23 (2012) No. 12, p. 905-926.

[76] N. Do, I. J. Choi, M. Song. Propagation of Engineering Changes to Multiple Product Data Views Using History of Product Structure Changes. International Journal of Computer Integrated Manufacturing. Vol. 21 (2008) No. 1, p. 19-32.

[77] D. C. Wynn, N. H. M. Caldwell, P. J. Clarkson. Can Change Prediction Help Prioritise Redesign Work in Future Engineering Systems. International Design Conference -Dubrovnik Croatia, 17- 20 May 2010.

[78] Roberto Raffaeli, Marco Malatesta, Eugenia Marilungo, et al. An Approach for Managing Engineering Changes in Product Families. ASME- International Design Engineering Technical Conferences. Portland, USA, 4-7 August 2013.

[79] Naveed Ahmad, David C. Wynn, P. et al. Change Impact on a Product and Its Redesign Process: A Tool for Knowledge Capture and Reuse. Res Eng Design. 29 August 2012. 
[80] Keith Phelan, Joshua D. Summers, Paolo Guarneri. Engineering Change ManagementVerification, Validation and Testing Planning Tool Development. Proceedings of TMCE, 19-23 May, 2014.

[81] Roberto Raffaeli, Michele Germani, Serena Graziosi, et al. Development of a Multilayer Change Propagation Tool for Modular Products. International Conference on Engineering Design. Paris, France, 28-31 August 2007.

[82] Chung-Yang Chen, Gen-Yih Liao, Ku-Shen Lin. An Attribute-Based and Object-Oriented Approach with System Implementation for Change Impact Analysis in Variant Product Design. Computer-Aided Design. Vol. 62 (2014), p. 203-217.

[83] Shan Zhao, Arman Oduncuoglu, Onur Hisarciklilar, et al. Quantification of Cost and Risk during Product Development. Computers \& Industrial Engineering. Vol. 76 (2014), p. 183-192.

[84] Seyed Amir Ahmadinejad, Ahmad Afshar. Management of Change Propagation in Mechatronic Product Design Based on Minimum Cost of Changes. RSI/ISM International Conference on Robotics and Mechatronics, Tehran, Iran, 15-17 October 2014.

[85] Bahram Hamraz, Nicholas H. M. Caldwell, Tom W. Ridgman, et al. FBS Linkage Ontology and Technique to Support Engineering Change Management. Res Eng Design. 3 June 2014.

[86] Genyuan Fei, James Gao, Dele Owodunni, et al. A Model-driven and Knowledge-based Methodology for Engineering Design Change Management. Computer-Aided Design and Applications. 09 Aug 2013. 